\title{
KOŚCIÓŁ KATOLICKI W NOWEJ HUCIE W OKRESIE GIERKOWSKIM. ROZWÓJ SIECI PARAFIALNEJ I BUDOWNICTWA SAKRALNEGO
}

\begin{abstract}
Wstęp
Nowa Huta w założeniach komunistycznych planistów miała być miastem nowym nie tylko w wymiarze architektoniczno-urbanistycznym, ale również socjologicznym. Opierając się na marksistowskiej teorii i stwarzając określone warunki życia zamierzano uformować nowego, postępowego człowieka. Ten nowoczesny mieszkaniec robotniczej aglomeracji miał być w pierwszym rzędzie pozbawiony jak powtarzali zgodnie marksistowscy teoretycy - dostępu do wszelkich katalizatorów dawnej tradycji, zwyczajów - a przede wszystkim religii. Nie może zatem dziwić fakt, iż w pierwotnych planach Nowa Huta miała być obszarem całkowicie pozbawionym jakichkolwiek instytucjonalnych wpływów Kościoła katolickiego ${ }^{1}$.

Jak czas pokazał rewolucyjne plany postępowych inżynierów społecznych szybko okazały się zwyczajną utopią, ale mimo to władza nie zamierzała łatwo oddawać pola i wszelkimi sposobami utrudniała rozwój oraz funkcjonowanie instytucji kościelnych w dzielnicy. Celem tego artykułu jest ukazanie jak w powyższych okolicznościach w okresie gierkowskim prezentowała się sieć parafialna i budownictwo sakralne na terenie Nowej Huty.

W artykule wykorzystano przede wszystkim materiały zdeponowane w Archiwum Narodowym w Krakowie, a należące do zespołu akt Urzędu Dzielnicowego w Nowej Hucie. Ponadto bazowano na dokumentach Kurii Metropolitalnej w Krakowie oraz Instytutu Pamięci Narodowej Oddział w Wieliczce. Przy pisaniu pracy pomocne okazały się również źródła drukowane i opracowania. Uzupełniająco korzystano z prasy i stron internetowych.
\end{abstract}

\section{Sieć parafialna}

Okres gierkowski to czas wyraźnej, acz reglamentowanej normalizacji w stosunkach państwo-Kościół. Już w 1971 r. KC PZPR i Urząd ds. Wyznań opracowa-

\footnotetext{
J. Purchla, Nowa Huta jako problem badawczy, w: Narodziny Nowej Huty: materiaty sesji naukowej odbytej 25 kwietnia 1998 roku, red. J. M. Małecki, Kraków 1999, s. 7-14; J. Ridan, Krzyż nowohucki. Dzieje walki o wiare $i$ wolność, Krzeszowice 2006, s. 7, 90; T. Gołaszewski, Kronika Nowej Huty, Kraków 1955, s. 66-71; J. Anioła, Huta im. Lenina, Warszawa 1954, s. 138-145.
} 
ły szereg ważnych dokumentów w duchu krytyki konfrontacyjnych metod polityki wyznaniowej, realizowanej w okresie rządów Gomułki. W ich konsekwencji odstąpiono m.in. od prowadzonej dotychczas w środkach masowego przekazu nachalnej antykościelnej propagandy, a zaczęto prezentować nowy wizerunek władzy gotowej do szczerego dialogu z Kościołem. Równocześnie jednak nowe otwarcie $\mathrm{w}$ stosunkach $\mathrm{z}$ episkopatem nie oznaczało bynajmniej rezygnacji z marksistowsko-leninowskich pryncypiów państwa, które ciągle nakazywały widzieć religię jako opium dla mas. Zmiana podejścia władz do Kościoła katolickiego miała zatem wymiar taktyczny, polegający na pozornym otwarciu przy rzeczywistym zachowaniu dotychczasowych celów, które nie uległy zmianie w czasach Gierka².

Potwierdzenie tezy o pozornym odprężeniu w stosunkach państwo-Kościół możemy bez problemu znaleźć również w różnych typach korespondencji wymienianej pomiędzy lokalnymi organami władzy. Świetnym tego przykładem jest choćby okólnik Prezydenta Miasta Krakowa z dnia 6 lutego 1976 r. dotyczący zasad uzgadniania z Wydziałem ds. Wyznań UMK spraw wyznaniowych. Ten poufny dokument powstał w konsekwencji pojawiających się na obszarze województwa miejskiego krakowskiego licznych przypadków nie przestrzegania procedur załatwiania spraw wyznaniowych. W piśmie skierowanym m.in. do naczelników dzielnic wyraźnie nakazuje się stosować zasady określone okólnikiem przez Prezesa Rady Ministrów jeszcze w 1960 r., dotyczące procedury postępowania terenowych organów administracji państwowej w sprawach wyznań. W tym kontekście upoważnionym do załatwiania spraw wyznaniowych w imieniu Prezydenta Miasta był lokalny Wydział ds. Wyznań, do którego obowiązków należały przede wszystkim nadzór nad merytorycznym rozstrzyganiem spraw dotyczących kościołów i innych związków wyznaniowych, podejmowanie decyzji w sprawach unormowanych dekretem z dnia 31 grudnia 1956 r. o organizacji i obsadzaniu stanowisk kościelnych, podejmowanie decyzji w sprawach uregulowanych ustawą z dnia 20 marca 1950 r. o przejęciu przez państwo „dóbr martwej ręki”, poręczeniu proboszczom posiadania gospodarstw rolnych i utworzeniu Funduszu Kościelnego (wraz z późniejszymi zmianami), a także podejmowanie decyzji w odniesieniu do fundacji, których majątki służyły lub miały służyć celom kultu religijnego lub innej działalności kościelnej. Wszystkie pozostałe sprawy związane z kościołem, duchownymi i pracownikami kościelnymi oraz stowarzyszeniami katolickimi, prowadzić miały wydziały (jednostki równorzędne) UMK i naczelnicy dzielnic oraz gmin w ścisłej współpracy z macierzystym Wydziałem ds. Wyznań3 ${ }^{3}$

Wbrew jednak oficjalnie głoszonej potrzebie dialogu przedstawicieli władzy państwowej z reprezentantami duchowieństwa w przytoczonym okólniku jasno stwierdzono, że „merytoryczne uzgadnianie decyzji z Wydziałem ds. Wyznań stanowi wyłącznie sprawę wewnętrzną organów administracji państwowej. Niedopuszczalnym

2 A. Dudek, R. Gryz, Komuniści i Kościół w Polsce (1945-1989), Kraków 2006, s. 281-282; J. Żaryn, Dzieje Kościoła katolickiego w Polsce (1944-1989), Warszawa 2003, s. 293.

3 Archiwum Narodowe w Krakowie [dalej: ANKr], sygn. UD Kr-NH, 2026/531, Okólnik nr 1/76 Prezydenta Miasta Krakowa z dn. 6 II 1976 r., k. 3. 
jest informowanie zainteresowanych [tj. przedstawicieli władz kościelnych] o obowiązku konsultacji, a tym bardziej kierowanie stron do Wydziału ds. Wyznań celem uzyskania jego zgody lub opinii”. Równocześnie nakazano wspomnianym jednostkom organizacyjnym UMK oraz organom administracji państwowej szczebla podstawowego uzyskanie merytorycznej opinii rzeczonego wydziału, nawet jeśli dana problematyka tylko pośrednio związana była z państwową polityką wyznaniową ${ }^{4}$.

Tymczasem obowiązkiem konsultacji objęto szeroki wachlarz spraw, co tylko potwierdzało rzeczywisty, a polegający na potrzebie kompleksowej kontroli i wyraźnym ograniczeniu swobody działania, stosunek władzy ludowej do instytucji kościelnych. Konsultacji podlegały przede wszystkim wszelkie sprawy z zakresu szeroko rozumianego budownictwa sakralnego (np. budowa, przebudowa lub rozbudowa infrastruktury kościelnej), które objęte były szczególną klauzurą postępowania administracyjnego. Ponadto nakaz konsultacji obejmował sprawy wewnętrzne (np. kwestie powoływania duchownych do służby wojskowej), gospodarcze, podatkowe i finansowe, ochrony zdrowia i opieki społecznej. Potrzebę konsultacji wymuszono także w kwestiach nauki, kultury i wychowania oraz w zwyczajnych sprawach lokalowych ${ }^{5}$.

Tak więc, oficjalnie deklarowane „ocieplenie” relacji na linii państwo-Kościół na przestrzeni dekady lat 70. XX w. miało dość ograniczony zakres i nie dotyczyło wielu obszarów przestrzeni publicznej, jak również konkretnie umiejscowionych parafii. Jednym z miejsc na mapie kraju, gdzie skutki politycznego odprężenia były zdecydowanie mniejsze od oczekiwań duchowieństwa, a przede wszystkim lokalnej społeczności wiernych, była Nowa Huta ${ }^{6}$.

Tabela 1. Rozkład jednostek organizacyjnych Kościoła katolickiego w ujęciu terenowym. Stan na dzień 31 XII 1978 r.

\begin{tabular}{|c|l|c|c|c|c|c|c|}
\hline L.p. & $\begin{array}{c}\text { Jednostka } \\
\text { administracji } \\
\text { państwowej }\end{array}$ & $\begin{array}{c}\text { Deka- } \\
\text { naty }\end{array}$ & Parafie & $\begin{array}{c}\text { Wikariaty } \\
\text { ekspono- } \\
\text { wane }\end{array}$ & $\begin{array}{c}\text { Rekto- } \\
\text { raty }\end{array}$ & $\begin{array}{c}\text { Ośrodki } \\
\text { dusz. }\end{array}$ & $\begin{array}{c}\text { Parafie } \\
\text { z pom. dek }\end{array}$ \\
\hline 1. & Krowodrza & 2 & 10 & 1 & - & 1 & 3 \\
\hline $\mathbf{2 .}$ & Nowa Huta & $\mathbf{1}$ & $\mathbf{7}$ & - & - & $\mathbf{8}$ & $\mathbf{8}$ \\
\hline 3. & Podgórze & 1 & 15 & 3 & - & 1 & 4 \\
\hline 4. & Śródmieście & 2 & 12 & - & - & 3 & 4 \\
\hline \multicolumn{2}{|l}{ RAZEM: } & 6 & 44 & 4 & - & 13 & 19 \\
\hline
\end{tabular}

Źródło: ANKr, sygn. UD Kr-NH, 2026/532, Biuletyn Informacyjny o stanie kościołów i związków wyznaniowych w województwie miejskim krakowskim, stan na dn. 31 XII 1978 r., k. 41.

4 ANKr, sygn. UD Kr-NH, 2026/531, Okólnik nr 1/76 Prezydenta Miasta Krakowa z dn. 6 II 1976 r., k. 3-5.

5 ANKr, sygn. UD Kr-NH, 2026/531, Okólnik nr 1/76 Prezydenta Miasta Krakowa z dn. 6 II 1976 r., k. 3-5.

6 J. L. Franczyk, Na fundamencie Krzyża. Kościót katolicki w Nowej Hucie w latach 19491989, Kraków 2004, s. 181. 
W 1978 r. w samym mieście Krakowie istniało 6 dekanatów, 44 parafie, 4 wikariaty eksponowane, 13 ośrodków duszpasterskich i 19 parafii funkcjonujących z pominięciem dekanatu. Tymczasem w administracyjnych granicach Nowej Huty zlokalizowany był 1 dekanat, 7 parafii oraz 8 ośrodków duszpasterskich. Zatem już na pierwszy rzut oka widać dość skromną, jak na gęstość zaludnienia i rozległy obszar dzielnicy, liczbę nowohuckich parafii w stosunku do pozostałych rejonów miasta. Jeszcze gorzej sytuacja wyglądała jeśli porówna się w ujęciu terenowym dane dotyczące liczby kościołów, kaplic, punktów katechetycznych czy plebani. Przykładowo w 1979 r. na obszarze Nowej Huty znajdowało się jedynie 7 kościołów z ogólnej liczby 85 istniejących w Krakowie. Dla porównania w Śródmieściu zlokalizowanych było 45 takiego typu obiektów sakralnych, w Podgórzu 18, a w Krowodrzy 15. Równie słabo Nowa Huta wyglądała pod względem liczby istniejących kaplic. W jej granicach w rzeczonym roku znajdowało się raptem 16 obiektów tego typu, z czego 8 stanowiło własność prywatną, zaś pozostałe miały status publicznych lub półpublicznych. Tymczasem na obszarze całego miasta istniało wówczas 148 kaplic, przy czym najwięcej bo aż 61 odnotowano w Śródmieściu. Również pod względem ilości dostępnych punktów katechetycznych Nowa Huta zajmowała ostatnie miejsce wśród krakowskich dzielnic. Na ogólną liczbę 90 punktów istniejących w 1979 r. w Krakowie, 29 funkcjonowało w Śródmieściu, 25 w Podgórzu, 19 w Krowodrzy i tylko 17 w Nowej Hucie. Przy czym na łączną liczbę nowohuckich punktów katechetycznych przypadało 10 zlokalizowanych w obiektach sakralnych lub kościelnych i $7 \mathrm{w}$ lokalach prywatnych. Nowohucka dzielnica zamykała także ranking ilości posiadanych plebanii. Na 44 istniejące plebanie w Krakowie raptem 7 znajdowało się w Nowej Hucie. Niemniej należy odnotować fakt, iż licząc łącznie wszystkie budynki kościelne zarejestrowane w poszczególnych dzielnicach miasta okazuje się, że w nowohuckiej enklawie było ich w sumie 16, a więc o jeden więcej niż w ostatniej pod tym względem Krowodrzy ${ }^{7}$.

Nienajlepszy obraz statystyczny struktury Kościoła katolickiego na obszarze Nowej Huty dopełniają dane dotyczące liczby zgromadzeń zakonnych umiejscowionych w tej dzielnicy. Szczególnie niekorzystna sytuacja panowała w segmencie zakonów męskich. Spośród 27 zgromadzeń ${ }^{8}$ istniejących w granicach Krakowa najwięcej, bo aż 16 funkcjonowało w Śródmieściu, a tylko jedno zlokalizowane było w nowohuckiej enklawie. Przy czym na ogólną liczbę 1047 krakowskich zakonników raptem 32 zameldowanych było w Nowej Hucie - a więc jedynie 3\% ogółu.

7 ANKr, sygn. UD Kr-NH, 2026/532, Biuletyn Informacyjny..., stan na dn. 31 XII 1978 r., k. 42-45; P. Natanek, Rozwój organizacji dekanalnej, parafialnej i katechetycznej $w$ archidiecezji krakowskiej za rządów ks. kard. Karola Wojtyly (1962-1978), Kraków 1993, s. 169-170.

8 Przedstawiona statystyka nie jest w pełni miarodajna, gdyż nie uwzględnia istnienia tych samych zgromadzeń w różnych jednostkach administracji państwowej, a została skonstruowana jedynie na potrzeby ujęcia terenowego omawianego zagadnienia jednostkowej liczby zakonów w poszczególnych dzielnicach miasta. 
Nieco lepsze statystyki odnotowano w przypadku zgromadzeń żeńskich. Na łączną liczbę 50 zakonów zarejestrowanych w dzielnicowych zestawieniach 26 odnotowano w Śródmieściu, 12 w Podgórzu, 8 w Krowodrzy i 4 w enklawie nad Dłubnią. Większy był również odsetek zakonnic z nowohuckim meldunkiem. Na 1869 sióstr zakonnych zapisanych w administracyjnej ewidencji miasta Krakowa 238 zameldowanych było w Nowej Hucie - co stanowiło prawie 13\% ogółu9 .

Zdecydowanie lepiej pod względem statystycznym wyglądała sytuacja Kościoła katolickiego na obszarze Nowej Huty jeśli porówna się dane zbiorcze dotyczące liczby parafii, proboszczów i wikariuszów odnotowanych w kurialnej ewidencji przed i po okresie gierkowskim. Widać to na przykładzie szczegółowych statystyk z lat 1967, 1972, 1977 i 1983. Na podstawie analizy poniżej przedstawionej tabeli dostrzegalna jest tendencja wyraźnego wzrostu liczby parafii i proboszczów na przestrzeni 16 lat z 5 do 8 (tj. o 60\% ogółu) oraz ilości wikariuszów z 18 do 37 (tj. 105\%). Natomiast odwrotną tendencję zanotowano w kategorii ilości nominalnych duchownych katechetów - spadek o ponad połowę ${ }^{10}$. Trzeba jednak pamiętać, iż na tle szybko wzrastającej liczby mieszkańców dzielnicy omawiane wskaźniki nie prezentowały się już tak okazale, jak wyglądały na pierwszy rzut oka.

Tabela 2. Liczba parafii, proboszczów, wikariuszy i katechetów z obszaru nowohuckiego Dekanatu Kraków VI w latach 1967, 1972, 1977 i 1983

\begin{tabular}{|l|c|c|c|c|c|}
\hline \multirow{2}{*}{ L. p. } & \multicolumn{4}{|c|}{ Liczba parafii, proboszczów, wikariuszy } & \multirow{2}{*}{$\begin{array}{c}\text { Przyrost } \\
\text { i katechetów w latach: }\end{array}$} \\
\cline { 2 - 5 } & $\mathbf{1 9 6 7}$ & $\mathbf{1 9 7 2}$ & $\mathbf{1 9 7 7}$ & $\mathbf{1 9 8 3}$ & \\
\hline 1. Parafie & 5 & 6 & 7 & 8 & $3 / 60 \%$ \\
\hline 2. Proboszczowie & 5 & 5 & 7 & 8 & $3 / 60 \%$ \\
\hline 3. Wikariusze & 18 & 27 & 30 & 37 & $19 / 105 \%$ \\
\hline 4. Katecheci & 13 & 8 & 7 & 6 & $-7 /-54 \%$ \\
\hline
\end{tabular}

Źródło: Katalog kościołów i duchowieństwa Archidiecezji Krakowskiej za rok 1967, Kraków 1967, s. 77-84; Katalog kościołów i duchowieństwa... za rok 1972, Kraków 1972, s. 95-102; Katalog kościołów i duchowieństwa... za rok 1977, Kraków 1977, s. 120-130; Katalog kościołów i duchowieństwa... za rok 1983, Kraków 1983, s. 143-155.

W okresie gierkowskim na terenie Nowej Huty leżały zasadniczo parafie: Bieńczyce, Czyżyny, Mogiła, Pleszów i Ruszcza oraz erygowana w 1976 r. nowa parafia w Mistrzejowicach. W konsekwencji reorganizacji sieci dekanalnej przeprowadzo-

9 ANKr, sygn. UD Kr-NH, 2026/532, Biuletyn Informacyjny..., stan na dn. 31 XII 1978 r., k. 47.

10 Katalog kościołów i duchowieństwa Archidiecezji Krakowskiej za rok 1967, Kraków 1967, s. 77-84; Katalog kościołów i duchowieństwa... za rok 1972, Kraków 1972, s. 95-102; Katalog kościołów i duchowieństwa... za rok 1977, Kraków 1977, s. 120-130; Katalog kościołów i duchowieństwa... za rok 1983, Kraków 1983, s. 143-155. 
nej w archidiecezji krakowskiej w lipcu 1971 r., obszar nowohuckiej enklawy po likwidacji dekanatu mogilskiego wszedł w skład dekanatu Kraków VI, który został poszerzony jeszcze o parafię w Raciborowicach. Dziekanem wspomnianego dekanatu został o. Jacek Stożek ${ }^{11}$.

Najstarszą parafią znajdującą się w granicach administracyjnych Nowej Huty była erygowana w 1222 r. parafia w Mogile. Na obszarze tej jednostki administracyjnej znajdował się konsekrowany w 1761 r. kościół parafialny pod wezwaniem św. Bartłomieja i kaplica parafialna Matki Boskiej Częstochowskiej. Oprócz nich, na terenie parafii zlokalizowane było Opactwo OO. Cystersów, gdzie mieścił się punkt katechetyczny. Nieopodal znajdowały się ponadto domy zakonne OO. Cystersów i SS. Józefitek, a także klasztor. To właśnie kościół klasztorny OO. Cystersów w marcu 1970 r. został wyróżniony przez papieża Pawła VI za swój zabytkowy charakter i istnienie żywego kultu Krzyża Świętego tytułem bazyliki mniejszej. Równocześnie warto pamiętać, że w latach 1925-1964 cała parafia Mogiła należała do dekanatu o tej samej nazwie, natomiast później znalazła się w składzie wspomnianego dekanatu Kraków VI. W 1977 r. mogilska parafia liczyła około 40 tys. mieszkańców, a w jej skład wchodziły osiedla: Centrum (od A do D), Handlowe (z wyjątkiem bloków 1-2), Hutnicze, Kępa, Lesisko, Młodości, Mogiła-Kopaniec, Mogiła pod Kopcem Wandy, Na Skarpie, Ogrodowe, Stalowe, Szkolne (bloki 1-5, 29-36), Szklane Domy, Wandy i Willowe. Do tej parafii należały również ulice: Bardosa, Bulwarowa, Daniłowskiego, Graby, Graniczna, Jagienki, Jeżynowa, M. Kasprzaka, Kępska, Klasztorna, Kmicica, K.K.P., Kopaniec, Na Niwach, Odmętowa, Orkana, Powiatowa, St. Samostrzelnika, Sieroszewskiego, Stare Wiślisko, Wojenna, Wołodyjowskiego, Zagłoby, Zakarnie, Zbyszka z Bogdańca, Ziarkowa, Z.M.P., Żaglowa, Żeromskiego oraz aleje Igołomska i Lenina ${ }^{12}$.

Trzeba jednak w tym miejscu nadmienić, iż wobec blokowania przez władze państwowe możliwości erygowania nowej parafii, która mogłaby być oficjalnie wyodrębniona z rozległego obszaru mogilskiej jednostki celem zapewnienia skuteczniejszej posługi duszpasterskiej nowohucianom mieszkającym na tym obszarze, metropolita krakowski podjął z dniem 14 października 1977 r. decyzję o wewnętrznym podziale tej jednostki na 2 rejony. Nowy rejon duszpasterski objął osiedla leżące przy Placu Centralnym (Centrum A, B, C, D) oraz Handlowe i Szklane Domy. Zarządcą tego rejonu został o. Niward Karsznia ${ }^{13}$.

Wracając do zasygnalizowanego wcześniej tematu opactwa należy zaznaczyć, iż klasztor OO. Cystersów zlokalizowany był dokładnie w osiedlu Mogiła pod nr

11 R. Bober, „, Krzyże w mieście bez Boga”. Organizacja parafialna w Nowej Hucie w okresie działalności kard. Karola Wojtyły w latach 1962-1978, Kraków 2006, s. 52, 65.

12 R. Bober, „Krzyże..., dz. cyt., s. 65-66; J. Raźny, Organizacja sieci parafialnej na terenie Nowej Huty w XX wieku, w: On tutaj byt... Karol Wojtyła w Nowej Hucie, oprac. red. R. Bober, W. Paduchowski, Kraków 2007, s. 25-29; A. Boniecki, Kalendarium życia Karola Wojtyty, Kraków 2000, s. 325; Katalog kościołów i duchowieństwa... za rok 1977, dz. cyt., s. 124.

13 J. L. Franczyk, Na fundamencie Krzyża.., dz. cyt., s. 229-230. 
226, a posiadał - jak wynika z materiałów archiwalnych Urzędu Dzielnicowego $370 \mathrm{~m}^{2}$ powierzchni użytkowej i $644 \mathrm{~m}^{2}$ powierzchni mieszkalnej ${ }^{14}$. Tymczasem na podstawie innych dokumentów wiemy na pewno, że na dzień 15 czerwca $1974 \mathrm{r}$. zameldowanych było w jego murach ogółem 36 zakonników, z czego 29 na pobyt stały, a 7 na czasowy. Ponadto w urzędowym wykazie meldunkowym księży i zakonnic odnotowano, iż z samego miasta Krakowa pochodziło raptem 3 duchownych. Przy czym $\mathrm{w}$ grupie zameldowanych $\mathrm{w}$ klasztorze przeważały osoby w przedziale wiekowym od 35 do 45 lat - było to w sumie 22 zakonników. Co ciekawe jednak najstarszy duchowny miał 69 lat, a najmłodszy niespełna $20^{15}$. Przeorem zakonu, a równocześnie administratorem parafii w Mogile i całego dekanatu pozostawał wówczas wspomniany już o. Jacek Stożek ${ }^{16}$.

W tym samym czasie - a dokładnie w dniu 15 czerwca 1974 r. - na obszarze mogilskiej parafii w domu zakonnym Zgromadzenia Sióstr Józefitek w osiedlu Mogiła pod numerem 219 zameldowanych było 11 zakonnic, z czego 6 na pobyt stały, a 5 na czasowy. Ponadto na podstawie dostępnych danych administracyjnych wiemy, iż większość zakonnic (7 spośród 11) znajdowała się wówczas w przedziale wiekowym od 40 do 45 lat. Przy czym najmłodsza siostra zakonna miała ukończone 27 lat, zaś najstarsza była w wieku 48 lat ${ }^{17}$. W latach 1972-1977 przełożonymi w domu zakonnym były kolejno siostry: Lucjana (Maria Sikoń) i Archangela (Maria Myja) ${ }^{18}$. Warto w tym miejscu dodać, iż do dyspozycji Sióstr Józefitek pozostawało łącznie $91 \mathrm{~m}^{2}$ przestrzeni lokalowej, na które składało się $77 \mathrm{~m}^{2}$ powierzchni mieszkalnej i $14 \mathrm{~m}^{2}$ powierzchni użytkowej ${ }^{19}$.

Druga w kolejność powstania na omawianym obszarze była erygowana w 1226 r. parafia w Pleszowie. Natomiast historia samego kościoła parafialnego sięga co najmniej wieku XIV - o czym zresztą wspomina w swoich kronikach Jan Długosz. Dopiero jednak po odbudowie, która miała miejsce na początku XIX w., kościół pod wezwaniem św. Wincentego Diakona Męczennika i Narodzenia NMP uzyskał współczesny kształt. W 1865 nastąpiła konsekracja tego obiektu sakralnego ${ }^{20}$.

14 ANKr, sygn. UD Kr-NH, 2026/528, Pismo UD Kr-NH do Wydziału ds. Wyznań Urzędu Wojewódzkiego w Krakowie z dn. 3 I 1974 r., k. 21-22.

15 ANKr, sygn. UD Kr-NH, 2026/529, Wykaz księży i zakonnic zameldowanych na terenie dzielnicy Nowa Huta, k. 69-81.

${ }_{16}$ Katalog kościołów i duchowieństwa... za rok 1977, dz. cyt., s. 125.

17 ANKr, sygn. UD Kr-NH, 2026/529, Wykaz księży i zakonnic zameldowanych na terenie dzielnicy Nowa Huta, k. 80-81.

18 Katalog kościołów i duchowieństwa... za rok 1972, dz. cyt., s. 407; Katalog kościołów i duchowieństwa... za rok 1977, dz. cyt., s. 513.

19 ANKr, sygn. UD Kr-NH, 2026/528, Pismo UD Kr-NH do Wydziału ds. Wyznań... z dn. 3 I 1974 r., k. 21-22.

20 A. Gliksman, Parafia i kościót św. Wincentego i Narodzenia Najświętszej Maryi Panny w Pleszowie, w: Nowa Huta - miasto krzyża i pracy, red. J. L. Franczyk, M. Lasota, J. Szczepaniak, Kraków 2009, s. 65-66; R. Bober, „Krzyże..., dz. cyt., s. 66. 
Parafia w Pleszowie od chwili powstania dekanatu mogilskiego wchodziła w jego skład. Niemniej dopiero reorganizacja dekanatów ogłoszona przez arcybiskupa Wojtyłę w 1964 r. umiejscowiła jej obszar w obrębie dekanatu Kraków VI, co kilka lat później potwierdzono kolejną kościelną reformą administracyjną. Na początku budowy Nowej Huty w 1949 r. rzeczona parafia liczyła 3702 wiernych. W 1971 r. liczba mieszkańców należących do tej jednostki administracyjnej osiągnęła już pułap około 20 tys. osób. Ten stan rzeczy utrzymał się zasadniczo do schyłku epoki gierkowskiej ${ }^{21}$.

Do parafii w Pleszowie w 1977 r. należały następujące miejscowości: Grębałów, Krzesławice, Lubocza - każde zamieszkiwane przez około 1000 osób, Pleszów (500 mieszkańców), Kujawy (400 mieszkańców), oraz dwa osiedla miejskie - Na Stoku i Wzgórza Krzesławickie, w których mieszkało łącznie około 16200 nowohucian. Dodatkowo pod zarządem pleszowskiej parafii znajdowały się: kaplica parafialna i kaplica w Zgromadzeniu Sióstr Norbertanek - obydwie zlokalizowane w Luboczy oraz kaplica u SS. Córek Bożej Miłości, a także kapliczka na cmentarzu w Pleszowie. Na terenie parafii funkcjonowało również wówczas kilka punktów katechetycznych. Były one umiejscowione przy kościele parafialnym w Pleszowie, przy kaplicy parafialnej na Wzgórzach Krzesławickich, przy kaplicy SS. Norbertanek w Luboczy oraz w miejscowościach Grębałów i Krzesławice. Proboszczem omawianej parafii przez cały okres lat 70. XX w. był ks. Jan Hyc ${ }^{22}$.

Kontynuując opis parafii w Pleszowie warto przyjrzeć się kwestii „kadry” duchownych sprawujących posługę kapłańską dla ludności w tej peryferyjnej enklawie miasta. $Z$ dostępnego zestawiania tabelarycznego opracowanego na podstawie danych meldunkowych księży i zakonnic zgromadzonych przez nowohucki Urząd Dzielnicowy wiemy na przykład dokładnie, kto personalnie w czerwcu 1974 r. sprawował posługę na terenie wspomnianej parafii. Jak wynika z archiwalnych dokumentów w sumie prawo pobytu będące w ewidencji pleszowskiego ośrodka duszpasterskiego posiadało 9 duchownych - z czego aż 7 księży na czas określony, przy jedynie 2 zameldowanych na stałe $\mathrm{w}$ dzielnicy ${ }^{23}$. Natomiast $\mathrm{z}$ dokumentów proweniencji kościelnej dowiadujemy się, że trzy lata później oprócz proboszcza - obowiązki kapłańskie pełniło w Pleszowie 5 wikarych ${ }^{24}$.

${ }^{21}$ P. Natanek, Rozwój organizacji dekanalnej, parafialnej i katechetycznej..., dz. cyt., s. 76-78; R. Bober, „Krzyże..., dz. cyt., s. 66; J. Raźny, Organizacja sieci parafialnej..., dz. cyt., s. 27-28.

22 R. Bober, „Krzyże w mieście bez Boga”. Organizacja parafialna..., dz. cyt., s. 66; Katalog kościołów i duchowieństwa... za rok 1972, dz. cyt., s. 99; Katalog kościołów i duchowieństwa... za rok 1977, dz. cyt., s. 126-127; Katalog kościołów i duchowieństwa... za rok 1983, dz. cyt., s. 153.

23 ANKr, sygn. UD Kr-NH, 2026/529, Wykaz księży i zakonnic zameldowanych na terenie dzielnicy Nowa Huta, k. 69-81.

${ }^{24}$ Katalog kościołów i duchowieństwa... za rok 1977, dz. cyt., s. 127. 
Kolejnym ważnym miejscem duszpasterskiej posługi pełnionej dla ludności Nowej Huty i okolicznych wiosek przez osoby duchowne w rejonie parafii Pleszów był Zakład Opiekuńczy dla Dzieci „Caritas” prowadzony przez Zgromadzenie Zakonne Córek Bożej Miłości. Na dzień 15 czerwca 1974 r. ogółem zameldowanych było w tej placówce dobroczynnej 26 zakonnic, z czego 22 siostry posiadały meldunek stały w dzielnicy, zaś 4 czasowy. Wiek zakonnic był wyraźnie zróżnicowany, przy czym najstarsza z sióstr widniejąca wówczas w ewidencji miała prawie 68 lat, a najmłodsza niespełna 24 ,wiosny" ${ }^{25}$. Przełożoną w tej placówce zakonnej była wówczas siostra Dominika (Agata Waleria) ${ }^{26}$. Przy czym budynek Zakładu „Caritas" posiadał łącznie $957 \mathrm{~m}^{2}$ powierzchni, na którą składało się $817 \mathrm{~m}^{2}$ powierzchni mieszkalnej i $140 \mathrm{~m}^{2}$ użytkowej ${ }^{27}$.

Innym zakonem żeńskim mającym swoje przedstawicielstwo na terenie parafii Pleszów, a dokładniej w Luboczy, było Zgromadzenie Sióstr Norbertanek. W styczniu 1974 r. 3 zakonnice $z$ tego zgromadzenia były zameldowane w budynku oznaczonym numerem 102, gdzie mieściło się wówczas przedszkole prowadzone przez Wydział Oświaty. Ogółem do dyspozycji sióstr pozostawało $166 \mathrm{~m}^{2}$, w tym $35 \mathrm{~m}^{2}$ powierzchni mieszkalnej i $131 \mathrm{~m}^{2}$ użytkowej ${ }^{28}$. Wiemy również, że we wspomnianym roku przeoryszą dla tej filialnej placówki prowadzonej przez norbertanki była siostra Immaculata (Maria Geisler) ${ }^{29}$.

Tymczasem najludniejszą jednostką w nowohuckim dekanacie były Bieńczyce. Parafię w Bieńczycach jako niezależną ekspozyturę erygował w dniu 15 czerwca 1952 r. arcybiskup Eugeniusz Baziak. Bieńczyckim kościołem parafialnym stała się wówczas istniejąca od 1893 r. w domu SS. Szarytek kaplica. Pierwszym proboszczem i zarazem administratorem został ks. Stanisław Kościelny. W chwili powołania do życia parafia liczyła około 3000 mieszkańców. Szybka rozbudowa nowohuckich osiedli mieszkaniowych we wspomnianej okolicy spowodowała, iż rzeczona parafia stała się w latach 70 . XX w. największym pod względem ilości wiernych ośrodkiem duszpasterskim w diecezji krakowskiej. W 1977 r. liczyła już przeszło 72 tys. mieszkańców. W skład bieńczyckiej parafii zarządzanej w okresie gierkowskim przez ks. proboszcza Józefa Gorzelanego - oprócz wsi Bieńczyce - wchodziły następujące osiedla miejskie: Dąbrowszczaków, XX-lecia PRL, Górali, Jagiellońskie, Kalinowe,

25 ANKr, sygn. UD Kr-NH, 2026/529, Wykaz księży i zakonnic zameldowanych na terenie dzielnicy Nowa Huta, k. 81-86.

${ }^{26}$ Katalog kościołów i duchowieństwa... za rok 1972, dz. cyt., s. 398-399; Katalog kościołów i duchowieństwa... za rok 1977, dz. cyt., s. 504.

27 ANKr, sygn. UD Kr-NH, 2026/528, Pismo UD Kr-NH do Wydziału ds. Wyznań... z dn. 3 I 1974 r., k. 21-22.

28 ANKr, sygn. UD Kr-NH, 2026/528, Pismo UD Kr-NH do Wydziału ds. Wyznań... z dn. 3 I 1974 r., k. 21-22.

${ }^{29}$ Katalog kościolów i duchowieństwa... za rok 1972, dz. cyt., s. 412; Katalog kościołów i duchowieństwa... za rok 1977, dz. cyt., s. 519-520. 
Kazimierzowskie, Krakowiaków, Na Lotnisku, Niepodległości, Słoneczne, Sportowe, Spółdzielcze, Strusia, Szkolne (bloki 6-17, 19, 22-24), Teatralne, Urocze, Wysokie, Zgody i Zielone. Na terenie parafii mieścił się również dom zakonny Zgromadzenia Sióstr Służebniczek Dębickich oraz punkt katechetyczny ${ }^{30}$.

$\mathrm{Na}$ podstawie materiałów archiwalnych Urzędu Dzielnicowego wiemy na pewno, iż w dniu 15 lipca 1975 r. wśród duchownych pełniących posługę w parafii Bieńczyce na terenie Nowej Huty zameldowanych było w sumie 11 duszpasterzy, z których tylko 4 posiadało stały meldunek, a aż 7 czasowy. $Z$ dostępnych danych dowiadujemy się również, że większość księży (co najmniej 6 z 11) było w przedziale wiekowym od 30 do 40 lat. Przy czym najstarszy duszpasterz był w wieku 59 lat, a najmłodszy ukończył 30 „wiosen”. Warty odnotowania jest także symptomatyczny fakt, iż aż 10 księży zamieszkiwało w osiedlach miejskich tzw. starej części dzielnicy, a tylko jeden nominalnie mieszkał w osiedlu wiejskim Bieńczyce. Co ciekawe, co najmniej dwóch duchownych - w tym proboszcz Józef Gorzelany - pochodziło z Krakowa ${ }^{31}$.

Jak wspomniano w 1977 r. parafia w Bieńczycach liczyła blisko 100 tysięcy wiernych, co czyniło ją najliczniejszą tego typu jednostką administracji kościelnej w Europie. To powodowało obiektywne trudności w sprawowaniu przez księży pracujących na tym terenie, skutecznej posługi. Nic dziwnego zatem, że już w 1974 r. czyniono pierwsze przymiarki do przeprowadzenia rejonizacji. Niemniej ostateczna decyzja kardynała Wojtyły o podziale parafii na cztery rejony duszpasterskie weszła w życie dopiero z dniem 20 sierpnia 1977 r. Reorganizacja spowodowała równocześnie, iż w poszczególnych rejonach duszpasterstwo miały sprawować zespoły duszpasterzy. W skład każdego zespołu wchodził duszpasterz rejonowy odpowiedzialny za dany rejon oraz 3 wikariuszów, którzy bezpośrednio i we wszystkim podlegali duszpasterzowi rejonowemu. W skład rejonu pierwszego weszły osiedla: Bieńczyce, Dąbrowszczaków, Górali, Jagiellońskie, Kazimierzowskie, Krakowiaków, Teatralne i Złota Jesień. Duszpasterzem tego rejonu został mianowany ks. Franciszek Skupień. Drugi rejon utworzyły osiedla: Słoneczne, Sportowe, Szkolne, Urocze, Zgody i Zielone. Na czele tego obszaru stał ks. Janusz Bielański. W skład trzeciego rejonu zostały wcielone enklawy: XX-lecia PRL, Kościuszkowskie, Niepodległości oraz Spółdzielcze. W tym rejonie lokalnym zwierzchnikiem był ks. Jan Zając. Ostatni - IV rejon - tworzyły osiedla: Kalinowe, Na Lotnisku, Strusia i Wysokie. Duszpasterzem rejonowym w tym przypadku był ks. Leon Baran. Wszystkie cztery rejony reprezentował na zewnątrz

${ }^{30}$ R. Bober, „,Krzyże..., dz. cyt., s. 68; J. Raźny, Organizacja sieci parafialnej..., dz. cyt., s. 30-31; E. Baniak, Kościót Matki Bożej Królowej Polski w Bieńczycach, w: Nowa Huta - miasto krzyża i pracy..., dz. cyt., s. 77-79; P. Natanek, Rozwój organizacji dekanalnej, parafialnej i katechetycznej..., dz. cyt., s. 101-103.

31 ANKr, sygn. UD Kr-NH, 2026/529, Wykaz księży i zakonnic zameldowanych na terenie dzielnicy Nowa Huta, k. 69, 103-104. 
proboszcz, którym pozostał do 1986 r. ks. Gorzelany ${ }^{32}$. Kościołem parafialnym Bieńczyc stała się konsekrowana w dniu 15 maja 1977 r. świątynia pw. Matki Bożej Królowej Polski zwana „Arką Pana”.

Wracając do kwestii zakonów działających w Nowej Huty przypomnijmy, że w okresie gierkowskim na terenie omawianej parafii w Bieńczycach funkcjonowało Zgromadzenie Sióstr Służebniczek Dębickich (Bogarodzicy Dziewicy Niepokalanie Poczętej) ${ }^{33}$. Na podstawie zachowanej archiwalnej ewidencji Urzędu Dzielnicowego zaprezentowanej w ujęciu tabelarycznym wiemy personalnie, które zakonnice pełniły posługę dla nowohucian. W $1974 \mathrm{r}$. zameldowanych pod adresem domu zakonnego znajdującego się w Bieńczycach pod numerem 43 było ogółem 10 sióstr zakonnych, z czego prawie wszystkie z wyjątkiem jednej osoby posiadały stały meldunek w Nowej Hucie. Pod względem metrykalnym połowa zakonnic znajdowała się wówczas w przedziale wiekowym od 40 do 50 lat. Przy czym najstarsza z sióstr służebniczek była w wieku 65 lat, a najmłodsza miała lat $30^{34}$. Przełożonymi rzeczonej placówki były w latach 1972-1983 kolejno siostry: Fidelisa (Zofia Noga), Maurylla (Łucja Cierniak) i Daria Janina Kozińska ${ }^{35}$.

Kolejną ważną jednostką w nowohuckiej sieci parafialnej - choć utworzoną formalnie dopiero w 1976 r. były Mistrzejowice. Najstarsze wzmianki o Mistrzejowicach pochodzą z 1270 r. Przez wieki ta niewielka wieś należała do parafii w Raciborowicach. W 1951 r. Mistrzejowice zostały włączone jako część Nowej Huty w obręb miasta Krakowa. Zanim jednak wieś zmieniła się w zaludnione osiedla miejskie musiało upłynąć prawie dwie dekady ${ }^{36}$. U schyłku okresu gomułkowskiego stało się jasne, iż na terenach Mistrzejowic powstanie czterdziestopięciotysięczny zespół nowych osiedli mieszkaniowych. W 1971 r. w osiedlu Tysiąclecia zamieszkiwało już 10 tys. osób, a budowane osiedle Złoty Wiek miało wkrótce zasiedlić dodatkowe 6 tys. lokatorów. Wobec braku własnego kościoła i parafii, część ludzi przypisana była do jednostki administracji kościelnej w Raciborowicach, a inni do pobliskich Bieńczyc. Natomiast pozostali w ogóle nie uczestniczyli w życiu religij-

32 Archiwum Kurii Metropolitalnej w Krakowie [dalej: AKMKr], sygn. APA 443, Pismo metropolity krakowskiego z dn. 29 VIII 1974 r., k. 893; AKMKr, APA 443, Odpis ustalenia dla duszpasterstwa w parafii pw. NMP Królowej Polski w Nowej Hucie Bieńczycach z dn. 11 VI 1977 r., k. 958; F. Skupień, Rejonizacja parafii NMP Królowej Polski w Nowej Hucie, w: On tutaj byt..., dz. cyt., s. 123-124; J. L. Franczyk, Na fundamencie Krzyża..., dz. cyt., s. 228-229; E. Baniak, Kościół Matki Bożej Królowej..., dz. cyt., s. 79.

33 R. Bober, ,Krzyże..., dz. cyt., s. 68.

34 ANKr, sygn. UD Kr-NH, 2026/529, Wykaz księży i zakonnic zameldowanych na terenie dzielnicy Nowa Huta, k. 83-84.

35 Katalog kościołów i duchowieństwa... za rok 1972, dz. cyt., s. 419; Katalog kościołów $i$ duchowieństwa... za rok 1977, dz. cyt., s. 528; Katalog kościołów i duchowieństwa... za rok 1983, dz. cyt., s. 576.

36 J. L. Franczyk, Historia powstania parafii i kościoła w Mistrzejowicach, w: On tutaj byt..., dz. cyt., s. 55-56. 
nym. Sytuacja zaczęła wymagać pilnych rozwiązań. Jak pisał w jednym ze swoich oficjalnych pism skierowanych do władz miasta kard. Wojtyła „potrzeba społeczna doprowadziła do trudnej, kontrowersyjnej i niezdrowej sytuacji, w rezultacie której powstał punkt katechetyczny, w którym prowadzona jest katechizacja już obecnie około 1000 dzieci" ${ }^{37}$.

Po kilku latach perturbacji, ostatecznie w dniu 20 września 1976 r. władze państwowe bez zastrzeżeń przyjęły pismo z Kurii o utworzeniu nowej parafii rzymskokatolickiej w Nowej Hucie. Finalny dekret w tej sprawie wydał kard. Wojtyła w dniu 4 października. Na jego podstawie w skład parafii pw. św. Maksymiliana Marii Kolbego wyodrębnionej z terenów parafii Raciborowice weszły osiedla: Bohaterów Września, Piastów, Tysiąclecia, Złoty Wiek oraz wieś Mistrzejowice. Granice nowej jednostki określono pomiędzy zbiegiem ulic Ostapa Dłuskiego i Krzesławicką do mostu na rzece Dłubnia, wzdłuż rzeki Dłubnia do toru kolejowego Lubocza-Batowice, a następnie od stacji Batowice drogą do przystanku autobusowego i dalej tą drogą przez pola w linii prostej do ul. Reduta. Wreszcie ulicą Reduta i Krzesławicką do jej zbiegu z ulicą Dłuskiego ${ }^{38}$. Ogółem w nowo utworzonym ośrodku duszpasterskim znalazło się około 30 tys. nowohucian. Pierwszym proboszczem parafii został ks. Mikołaj Kuczkowski, który miał do pomocy 5 wikariuszy. Natomiast nowym kościołem parafialnym stała się wybudowana w latach 1975-1979 świątynia pw. św. Maksymiliana Kolbego. Równocześnie na terenie parafii swoją działalność zaczął prowadzić Dom Zakonny SS Służebniczek Starowiejskich. Przełożoną placówki od 1977 r. była siostra Helena Dec ${ }^{39}$.

Kończąc opis nowohuckiej sieci parafialnej w okresie gierkowskim nie wolno nam zapomnieć o pomniejszych, a leżących na peryferiach dzielnicy, kościelnych jednostkach administracyjnych. Do tego grona zaliczyć należy parafie w Czyżynach, Ruszczy i Raciborowicach.

Parafia w Czyżynach została erygowana 15 kwietnia 1951 r., a jej pierwszym administratorem został ks. Józef Zastawniak. Kościołem parafialnym stała się wówczas wybudowana jeszcze jesienią 1939 r. świątynia pod wezwaniem św. Judy Tadeusza. W 1954 r. parafia, w skład której wchodziły Czyżyny, Wieczysta i Łęg liczyła 4335 wiernych. Po reformach sieci dekanalnej zmianom uległy granice czyżyńskiej jednostki. W 1977 r. parafia obejmowała mieszkańców macierzystej enklawy wiejskiej Czyżyny oraz Łęg i dwa osiedla miejskie Kolorowe oraz część Handlowego (bloki nr 1 i 2). W sumie na jej obszarze zamieszkiwało we wspomnianym okresie

37 J. L. Franczyk, Na fundamencie Krzyża..., dz. cyt., s. 198.

38 AKMKr, sygn. APA 458, Decyzja Prezydenta Miasta Krakowa z dn. 20 IX 1986 r.; J. L. Franczyk, Na fundamencie Krzyża..., dz. cyt., s. 224-226; P. Natanek, Rozwój organizacji dekanalnej, parafialnej i katechetycznej..., dz. cyt., s. 112.

39 Katalog kościołów i duchowieństwa... za rok 1977, dz. cyt., s. 123-124, 531; B. Frydel, K. Szumal, Ks. kanonik Józef Kurzeja: „Pragnieniem moim jest wybudować kościót w Mistrzejowicach...”, Kraków 1998, s. 90-91. 
10400 wiernych, którzy mieli do swojej dyspozycji dwa punkty katechetyczne zlokalizowane w Czyżynach i w Łęgu ${ }^{40}$. W dniu 15 lipca 1975 r. posługę w tym rejonie pełniło 4 duchownych, w tym sprawujący funkcje proboszcza parafii w latach 1961-1986 ks. Stanisław Michałek. Wszyscy zamieszkiwali w pobliżu czyżyńskiego kościoła ${ }^{41}$.

Inną parafią, która znajdowała się na peryferiach nowohuckiej dzielnicy była erygowana jeszcze w 1312 r. jednostka administracyjna w Ruszczy. Rolę kościoła parafialnego, którego data konsekrowania nie jest dokładnie znana, pełniła świątynia pod wezwaniem św. Grzegorza Wielkiego papieża. Drugim patronem parafii była Matka Boża Różańcowa. W roku rozpoczęcia budowy Nowej Huty, parafia w Ruszczy bez miejscowości Dojazdów i Krzysztoforzyce liczyła 3280 mieszkańców. Prawie trzy dekady później - w 1977 r. - liczbę wiernych szacowano na 5400 osób. W granicach parafii znajdowały się wówczas osiedla wiejskie Ruszcza (387 mieszkańców), Branice i Stryjów (łącznie 616 osób), Chałupki i Holendry (łącznie 504 mieszkańców), Dojazdów (607 osób), Krzysztoforzyce (390 osób), Łuczanowice (478 osób), Przylasek Rusiecki (231 osób), Przylasek Wyciązki (323 osoby), Wadów (843 osób) oraz Wyciąże (1021 osób). Na terenie parafii funkcjonowało w omawianym okresie 5 punktów katechetycznych. Były one zorganizowane w Ruszczy przy „Organistówce”, w kaplicy w Łuczanowicach, a także w osiedlach Branice, Przylasek Rusiecki i Wyciąże. Proboszczem parafii był wówczas ks. Józef Karkula, który miał do pomocy jednego wikariusza oraz księdza rezydenta ${ }^{42}$.

Ostatnią niewielką parafią, której kościelne granice częściowo nakładały się na administracyjny obszar dzielnicy Nowa Huta, była erygowana wedle zapisów Jana Długosza jeszcze w 1325 r. parafia w Raciborowicach. Lokalny kościół parafialny pod wezwaniem św. Małgorzaty został konsekrowany w 1473 r. W 1949 r. do parafii w Raciborowicach liczącej wówczas 2390 mieszkańców należały: Bieńczyce, Batowice, Kantorowice, Mistrzejowice, Zesławice. Po dwóch reorganizacjach sieci dekanalnej przeprowadzonej w diecezji krakowskiej zmieniły się znacząco granice rzeczonej parafii. W $1977 \mathrm{r}$. do tej jednostki administracyjnej należały następujące miejscowości: Raciborowice (374 osoby), Raciborowice-Prawda (103 osoby), Batowice (284 osób), Boleń (132 osoby), Bosutów (194 osoby), Dziekanowice (423 osoby), Kantorowice (359 osób), Kończyce (184 osoby), Prusy (574 osoby), Sulechów (293 osoby), Zastów (476 osób), Zesławice Osiedle (400 osób), Zesławice Wieś i Dłubnia (łącznie 190 osób). Liczba mieszkańców osiągnęła wtenczas dokładnie

40 R. Bober, „Krzyże..., dz. cyt., s. 68; J. Gwizdoń, Kościół św. Judy Tadeusza w Czyżynach, w: Nowa Huta - miasto krzyża i pracy..., dz. cyt., s. 73-74; Katalog kościołów i duchowieństwa... za rok 1977, dz. cyt., s. 122-123.

${ }^{41}$ ANKr, sygn. UD Kr-NH, 2026/529, Wykaz księży i zakonnic zameldowanych na terenie dzielnicy Nowa Huta, k. 72, 103-104; J. Raźny, Organizacja sieci parafialnej..., dz. cyt., s. 30 .

42 R. Bober, „Krzyże..., dz. cyt., s. 66-67; J. Raźny, Organizacja sieci parafialnej..., dz. cyt., s. 28; Katalog kościołów i duchowieństwa... za rok 1977, dz. cyt., s. 128-129. 
poziom 4086 osób. Na terenie parafii znajdowały się w omawianym okresie dwie kaplice - w Prusach i w Domu Rencisty w Batowicach. Ponadto odnotowano trzy punkty katechetyczne - w Prusach, w Kantorowicach i w Domu Katolickim w Raciborowicach. Funkcję proboszcza pełnił we wspomnianym roku ks. Stanisław Migas będący także notariuszem dekanatu. Na terenie parafii mieszkało oprócz niego jeszcze dwóch duchownych, z których jeden był rektorem kaplicy w Prusach ${ }^{43}$.

Konkludując, możemy śmiało odnotować, że w czasie dekady gierkowskiej na obszarze Nowej Huty nastąpiły znaczące przeobrażenia w istniejącej dotychczas sieci parafialnej. Szczególnie ważne wydaje się w tym kontekście wyodrębnienie w 1976 r. nowej jednostki administracji kościelnej w Mistrzejowicach. Niemniej istotne były również zmiany związane z powołaniem w $1977 \mathrm{r}$. w parafiach Bieńczyce i Mogiła nowych rejonów duszpasterskich. Mówiąc o sieci parafialnej nie wolno nam zapominać także o istniejących na terenie dekanatu Kraków VI zgromadzeniach zakonnych. W sumie w omawianym okresie na terenie dzielnicy funkcjonowało 6 zgromadzeń - 1 męskie (Cystersi) i 5 żeńskich (Córki Bożej Miłości, Józefitki, Norbertanki, Służebniczki Dębickie i Służebniczki Starowiejskie).

\section{Budownictwo sakralne}

Niezwykle ważną z punktu widzenia szeroko rozumianych interesów Kościoła katolickiego - nie tylko w Nowej Hucie, ale na obszarze całego kraju - była kwestia budownictwa sakralnego. Komunistyczne władze doskonale zdawały sobie sprawę z powagi oczekiwań w tej mierze zarówno biskupów oraz niższego duchowieństwa, jak i samych wiernych. W okresie gierkowskim w kontekście „normalizacji” stosunków państwa z Kościołem, nastąpiło pewnego rodzaju taktyczne odprężenie, które doprowadziło do odczuwalnego zwiększenia liczby zezwoleń na budowy nowych świątyń względem lat 60 . Systematycznie wzrastała liczba pozwoleń. Przykładowo w 1971 r. wydano w skali kraju 28 takich pozytywnych decyzji. W 1972 r. było ich 31, w 1973 r. już 58. Natomiast rok później pozwolono na 60 inwestycji sakralnych. W drugiej połowie dekady utrzymano dotychczasową tendencję, co spowodowało że w latach 1975-1979 aparat wyznaniowy wydał łącznie 228 zezwoleń na nowe kościoły i kaplice. Oczywiście pozwolenia stanowiły tylko część odpowiedzi na zgłaszane wnioski kurii diecezjalnych. Na ten przykład w województwie krakowskim w latach 1975-1980 na 183 wnioski dotyczące budownictwa sakralnego zgłoszone przez kurie do właściwych organów władzy państwowej pozytywnie rozpatrzono zaledwie $18 \mathrm{z}$ nich - a więc niecałe $10 \%$ ogółu. Władza zwana ludową przez cały okres gierkowski stosowała taktykę możliwie długiego blokowania budowy świątyń w nowych miastach i osiedlach, tam gdzie istniały największe potrzeby społeczne. Natomiast celem rozładowania napięć zdecydowanie chętniej była

43 R. Bober, „Krzyże..., dz. cyt., s. 67; J. Raźny, Organizacja sieci parafialnej..., dz. cyt., s. 28; Katalog kościołów i duchowieństwa... za rok 1977, dz. cyt., s. 129-130. 
skora wydawać koncesje na remonty, odbudowę czy rozbudowę już istniejących obiektów sakralnych ${ }^{44}$.

Tymczasem kwestia budownictwa sakralnego zdeterminowała w latach 70. działania zarówno duchownych, jak i wiernych z rejonu Nowej Huty. Trzeba pamiętać bowiem, że komunistyczni decydenci na tym terenie długo i skutecznie torpedowali wszelkie próby legalnej budowy pierwszego kościoła. Dopiero potężna presja społeczna wsparta staraniami przedstawicieli episkopatu, w której szczególną rolę odegrał metropolita krakowski kard. Wojtyła oraz administrator bieńczyckiej parafii ks. Gorzelany, jak również interwencje wysłanników papieża Pawła VI, przyczyniły się do zatwierdzenia w maju 1967 r. przez władze wstępnego projektu rozbudowy kaplicy w Bieńczycach. W końcu jesienią wspomnianego roku ruszyła długo wyczekiwana budowa słynnej nowohuckiej „Arki Pana”45.

Postacią bez której trudno sobie wyobrazić skuteczną finalizację budowy pierwszego kościoła na obszarze nowo wznoszonej dzielnicy był wspomniany wcześniej ksiądz proboszcz Józef Gorzelany. Już w grudniu 1970 r. Służba Bezpieczeństwa pisała o nim w poważnym tonie. „Wymieniony wprowadza w parafii coraz to nowe środki mające pobudzać wiernych do skupiania się wokół parafii, a przede wszystkim do składania ofiar na budowę kościoła"46. Wedle świadectwa samego zainteresowanego tylko w rzeczonym roku władze administracyjne i SB przeprowadziły 40 kontroli na kościelnym placu budowy, starając się maksymalnie utrudnić pracę robotnikom - zresztą wielu z nich dodatkowo szykanując w miejscu ich stałego zatrudnienia lub zamieszkania ${ }^{47}$.

Pomimo rozmaitych trudności - zarówno materiałowych, jak urzędniczych na zakończenie 1970 r. stały już 3 z 4 monumentalnych ścian przyszłego obiektu. W czerwcu 1971 r. - nie bez kolejnych trudności - udało się zamontować składającą się z trzech części o wadze 30, 25 i 12 ton oraz łącznej długości 23 m podstawę krzyża-masztu. Dzięki temu można było stawiać ścianę tzw. żaglową i antresolę. W lipcu nadszedł z Linzu w Austrii kolejowy transport 12 ton stali nierdzewnej na okładzinę wspomnianego krzyża-masztu, a do końca jesieni udało się wybudować zbrojenie najtrudniejszej technicznie do wykonania ściany żaglowej. Równocześnie trwała nieprzerwanie akcja zbierania datków pieniężnych na budowę świątyni prowadzona w kraju i poza jego granicami. Tymczasem budowa postępowała w szybkim tempie. W 1972 r. postawiono ostatnią ścianę kościoła i rozpoczęto wznoszenie symbolicznego w swojej formie dachu w kształcie biblijnej łodzi. Równolegle z pracami bu-

44 R. Gryz, Pozwolić czy nie? Władze PRL wobec budownictwa katolickich obiektów sakralnych $w$ latach 1971-1980, Kielce 2007, s. 152, 159, 176-179.

45 J. Gorzelany, Gdy nadszedt czas budowy Arki. Dzieje budowy kościoła w Nowej Hucie, Paryż 1988, s. 123-143; J. L. Franczyk, Na fundamencie Krzyża..., dz. cyt., s. 170-180.

46 Instytut Pamięci Narodowej Oddział w Krakowie [dalej: IPN Kr], sygn. IPN Kr, 021/25, t. 2, Pismo ppłk. Władysława Żyły do Naczelnika Wydziału IV SB KW MO w Krakowie z dn. 1 XII 1970 r., k. 32.

47 J. L. Franczyk, Na fundamencie Krzyża.., dz. cyt., s. 182. 
dowlanymi przy świątyni prowadzono budowę plebani. Władze jednak nie godziły się na rozbudowę zaplecza mieszkalnego dla sióstr i księży wikariuszy pracujących w parafii oraz na dodatkowe salki katechetyczne. Zgoda dotyczyła jedynie wzniesienia kancelarii, mieszkania dla proboszcza i jednego wikarego oraz jednej osoby świeckiej, do tego można było dobudować pomieszczenia gospodarcze. Ksiądz Gorzelany miał jednak inną wizję i naniósł zmiany na projekt budowlany przy czym nie odbyło się to bez sporu z władzami samej Kurii Metropolitalnej. W końcu niejasności zostały wyjaśnione w wyniku osobistej rozmowy proboszcza Bieńczyc z kard. Wojtyłą. Pod koniec 1973 r. Zarząd Gospodarki Przestrzennej i Ochrony Środowiska przy Prezydium Rady Narodowej Miasta Krakowa wydał zgodę na użytkowanie części plebani ${ }^{48}$.

Kilka miesięcy później, a dokładnie w dniu 12 kwietnia 1974 r., władze wydały również oficjalną zgodę na użytkowanie pierwszej kaplicy w „Arce Pana”. W tym samym roku wewnątrz kościoła wykonano siedemnastometrową ścianę organową oraz antresolę o długości $60 \mathrm{~m}$ i szerokości $14 \mathrm{~m}$, która stanowiła trzeci najwyższy poziom świątyni. Tymczasem 29 listopada rzeczonego roku miały miejsce dwa niepokojące wydarzenia. Z rana odkryto, że dolna Kaplica Pojednania została zalana wodą do wysokości $20 \mathrm{~cm}$. Wiele wskazywało na działania operacyjne SB w tym względzie. Natomiast popołudniu tego samego dnia doszło do tragicznego w skutkach wypadku na budowie. Śmierć poniósł jeden z 4 cieśli, którzy spadli z 7 metrowego rusztowania. Na polecenie władz pracę na pewien czas wstrzymano, ale obyło się bez dalszych reperkusji. Prokuratura pół roku później umorzyła śledztwo. Rok 1975 upłynął tymczasem na pracach wykończeniowych. Natomiast w 1976 r. pilną potrzebę stanowiło uzyskanie od władz pozwolenia na zamontowanie wieńczącego budowlę krzyża na maszcie łodzi, który znacząco przekraczał dopuszczoną maksymalną wysokość kościoła ustaloną na 26 metrów. Zgodę udało się ostatecznie uzyskać, a w dniach 11-16 listopada ekipy robotników przy pomocy wypożyczonego z „Mostostalu” dźwigu w asyście rzeszy parafian i samego kardynała Wojtyły zamontowały symboliczny krzyż. Jego łączna wysokość mierzona od dolnej podstawy wyniosła 70 metrów i robiła iście piorunujące wrażenie. Równocześnie w latach 1976-1977 kontynuowano prace wykończeniowe związane z wystrojem wnętrza świątyni. W centralnym miejscu kościoła umieszczono ołtarz, a obok niego tabernakulum w kształcie kuli o porowatej powierzchni. Po drugiej stronie ołtarza ulokowano kopię obrazu Matki Boskiej Zbaraskiej. Wystrój ołtarza uzupełniła droga krzyżowa w formie płaskorzeźb w stali nierdzewnej. Natomiast na zewnątrz świątyni na długiej betonowej belce przylegającej do murów kościoła, zawieszono 8 dzwonów będących darem holenderskich katolików. Dzwony otrzymały imiona osób, które najbardziej przyczyniły się do wzniesienia tej budowli sakralnej ${ }^{49}$.

48 J. Gorzelany, Gdy nadszedt czas budowy Arki..., dz. cyt., s. 180-188; J. L. Franczyk, Na fundamencie Krzyża..., dz. cyt., s. 181-190.

49 J. L. Franczyk, Na fundamencie Krzyża..., dz. cyt., s. 215-218; J. Gorzelany, Gdy nadszedt czas budowy Arki..., dz. cyt., s. 221-231. 
W dniu 15 maja 1977 r. - po 10 latach od inauguracji prac budowlanych, a po 28 latach od rozpoczęcia budowy Nowej Huty - metropolita krakowski ks. kard. Karol Wojtyła konsekrował kościół pod wezwaniem Matki Bożej Królowej Polski potocznie zwany „Arką Pana”. Pomimo ulewnego deszczu blisko 70 tysięczny thum wiernych, który przybył nie tylko z okolicznych nowohuckich parafii, ale także z innych dzielnic miasta, stron kraju, a nawet odległych zakątków świata, przeżywał wielkie chwile duchowego uniesienia. Wśród zaproszonych gości nie zabrakło wysokich hierarchów katolickiego duchowieństwa i przedstawicieli placówek dyplomatycznych. Obecni byli także reprezentanci środowisk polonijnych. Wydarzenie to odbiło się szerokim echem w przestrzeni medialnej, a gratulacje w formie listów i telegramów napływały niemal ze wszystkich kontynentów. Nowa Huta doczekała się w końcu swojej nowej świątyni ${ }^{50}$. Na marginesie tego wydarzenia warto wspomnieć, iż władze państwowe celem ograniczenia wpływu uroczystości konsekracji na mieszkańców dzielnicy wyznaczyły dokładnie na ten sam dzień propagandową akcję zwaną Niedzielą Czynu Partyjnego ${ }^{51}$.

Jeśli piszemy o kwestii budownictwa sakralnego w ramach zabiegania lokalnej ludności dzielnicy o własny kościół, to równie dużym determinizmem w staraniach co mieszkańcy Bieńczyc wykazali się parafianie z Pleszowa, zamieszkali w peryferyjnych osiedlach Wzgórza Krzesławickie, Na Stoku i Grębałów. Początek ubiegania się przez ludność tego rejonu miasta o zgodę na wzniesienie nowej placówki kościelnej datuje się na połowę lat 60 . XX w. i związana jest z postacią ówczesnego administratora parafii ks. Jana Hyca, który - jak wynika z raportów SB - mocno dawał się we znaki władzom państwowym aranżując bez zezwolenia m.in. punkty modlitewno-katechetyczne ${ }^{52}$.

W kontekście omawianego zagadnienia trzeba mieć na uwadze, iż wskutek rozbudowy kombinatu metalurgicznego postępowała terytorialna dezintegracja pleszowskiej parafii, która składała się w zasadzie z trzech odrębnych części. Nowe osiedla miejskie zamieszkałe przez kilkanaście tysięcy osób, a powstałe na północnych rubieżach dzielnicy, znajdowały się bowiem w odległości około $7 \mathrm{~km}$ od starego kościoła parafialnego w Pleszowie. Również pobliskie Kujawy zostały fizycznie odcięte od macierzystej jednostki. To wszystko znacząco utrudniało posługę duszpasterską. Pewnego rodzaju wstępem do budowy kościoła u schyłku epoki Gomułki było wspomniane organizowanie punktów katechetycznych i początek funkcjonowania kapliczki w pomieszczeniach gospodarczych na tzw. Niebyle. Lata 70. upłynęły natomiast na żmudnych staraniach o pozwolenie na budowę nowego kościoła.

50 J. Gorzelany, Gdy nadszedt czas budowy Arki..., dz. cyt., s. 226-227.

51 AKMKr, sygn. APA 443, List metropolity krakowskiego kard. Karola Wojtyły do Przewodniczącego Rady Narodowej WMK Wita Drapicha z dn. 12 V 1977 r., k. 925; 15 Maja-dniem ogólnopartyjnego czynu, „Głos Nowej Huty” 1977, nr 1063, s. 1.

52 IPN Kr sygn. IPN Kr 021/25, t. 2, Pismo ppłk. Władysława Żyły do Naczelnika Wydziału IV SB KW MO w Krakowie z dn. 1 XII 1970 r., k. 31-32; J. Głód, Powstanie parafii i kościoła na Wzgórzach Krzesławickich, w: On tutaj byt..., dz. cyt., s. 77. 
W styczniu 1972 r. grupa mieszkańców wspomnianych osiedli złożyła oficjalną petycję do DRN o zgodę na inwestycję sakralną. Podobne pisma na przestrzeni lat parafianie słali do władz miejskich i rządowych. Starania mieszkańców niejednokrotnie wspierał z ambony, jak również interweniując pisemnie u świeckich decydentów, ówczesny kardynał Karol Wojtyła. Szczególnie zapadła tysiącom wiernym w pamięci wygłoszona przez niego homilia w grudniu 1977 r. na Pasterce odbytej właśnie na Wzgórzach Krzesławickich. Komunistyczne władze były jednak ciągle nieugięte piętrząc celowo trudności administracyjne, a przy okazji szykanując mocno zaangażowanych w sprawę księży i parafian. Swoje zadania sumiennie realizowała w tym względzie SB. Nadszedł jednak w końcu długo wyczekiwany moment. W dniu 24 maja 1980 r. prezydent miasta Krakowa Edward Barszcz wydał pozwolenie na budowę kościoła na Wzgórzach Krzesławickich, który wkrótce przyjął patronat Miłosierdzia Bożego. Rok później ks. kard. Franciszek Macharski erygował w tym miejscu nową nowohucką parafię ${ }^{53}$. Natomiast sama świątynia została wybudowana dopiero w latach 1982-198754.

Podobny deficyt kościelnych obiektów sakralnych oraz pomocniczych panował w szybko rozwijającym się, a sąsiadującym z Bieńczycami, rejonie Mistrzejowic. W tym przypadku duchownym, z którym bezsprzecznie należy wiązać początek starań o budowę nowego kościoła i powołanie pierwszego w Mistrzejowicach punktu katechetycznego był ks. Józef Kurzeja. Kapłan ten mianowany wikariuszem rozpoczął swoją posługę w parafii Raciborowice w 1968 r., i postanowił zrazu objąć opieką duszpasterską mieszkańców nowo powstającego blokowiska. Wobec niemożności znalezienia odpowiedniego lokum na salki katechetyczne ani w blokach na os. Tysiąclecia, ani w domkach jednorodzinnych na Prądniku Czerwonym - ks. Kurzeja zdecydował się na postawienie w nocy z 26 na 27 sierpnia 1970 r. bez zezwolenia władz administracyjnych, drewnianego baraku zwanego później „zielona budką”. Kameralna budka o wymiarach 5x6 metrów stała w niewielkim zagajniku w odległości około $400 \mathrm{~m}$ na południowy zachód od osiedla Tysiąclecia, zaledwie kilkadziesiąt metrów od ul. Ostapa Dłuskiego, łączącej Nową Hutę z Krakowem. Dzięki pomalowanej na zielono „elewacji” obiekt zlewał się optycznie z otoczeniem. Wewnątrz budki ustawiono stół i ławki. Na ścianie zawisł natomiast krzyż oraz dwa święte obrazy - Matki Bożej Częstochowskiej i Ojca Maksymiliana Kolbego ${ }^{55}$.

53 AKMKr, sygn. APA 244, Wizytacja parafii Nowa Huta-Pleszów 1-2 II i 5-11 IV 1976 r.; J. Głód, Powstanie parafii i kościoła na Wzgórzach Krzesławickich..., dz. cyt., s. 77-82; http://www.wzgorza.diecezja.krakow.pl/article.php/20100207143410786 [dostęp: 28 I 2019 r.].

54 J. S. Wroński, Kościót Miłosierdzia Bożego na Wzgórzach Krzesławickich, w: Budujemy kościót. Współczesna architektura sakralna w Nowej Hucie, red. M. Niezabitowski i in., Kraków 2010, s. 52.

55 AKMKr, sygn. APA 458, Wizytacja parafii Mistrzejowice - Nowa Huta 10-14 XI 1976 r.; B. Frydel, K. Szumal, Ks. kanonik Józef Kurzeja..., dz. cyt., s. 22-27. 
Komunistycznym urzędnikom nie przypadł bynajmniej do gustu plan katechizacji mieszkańców pobliskich osiedli w ,zielonej budce” toteż w każdy możliwy sposób utrudniali duszpasterską posługę księdzu Kurzei szykanując go dostępnymi metodami administracyjnymi. Tylko w samym $1971 \mathrm{r}$. aż 20-krotnie duchowny uczestniczył $\mathrm{w}$ wielogodzinnych przesłuchaniach, na które został wezwany przez SB. Dodatkowo w latach 1970-1972 władze wydawały kilkakrotnie poprzez Wydziały Budownictwa, Urbanistyki i Architektury dzielnicowej oraz miejskiej Rady Narodowej decyzje o rozbiórce rzeczonej „samowoli budowlanej”. Budowa kapliczki pociągała za sobą także kary finansowe orzekane przez miejscowe Kolegium Karno-Administracyjne dla osób duchownych i świeckich zaangażowanych w przedmiotową inicjatywę. W sytuacji pogłębiającego się kryzysu na linii mieszkańcy-władza, w dniu 24 grudnia 1971 r. do Mistrzejowic przyjechał na Pasterkę kardynał Karol Wojtyła i wsparł z ambony w swoim kazaniu starania o nową świątynię. Uczynił to także wykorzystując oficjalną drogę administracyjną ${ }^{56}$.

Dużym, acz pozytywnym, zaskoczeniem dla wiernych była decyzja kierownika Wydziału ds. wyznań PRN w Krakowie z dnia 8 lipca 1972 r. zezwalająca na „przeniesienie kościoła w Pleszowie w rejon osiedli Mistrzejowic”. Określenie „przeniesienie” było pewnego rodzaju fortelem dającym de facto zgodę na rozpoczęcie budowy nowej świątyni. W decyzji administracyjnej była ukryta jednak jeszcze jedna zagadka. Kuria Metropolitalna co prawda starała się od dłuższego czasu o „przeniesienie” kościoła z pochłanianej przez kombinat i skazanej na likwidację wsi Pleszów, ale na teren osiedla Wzgórza Krzesławickie - tymczasem zgoda dotyczyła Mistrzejowic. Pozytywną wiadomością było natomiast, że pozwolenie dotyczyło także budowy sal katechetycznych i mieszkań dla księży. Równocześnie skomplikowała się wówczas sytuacja ks. Kurzei, który wedle przepisów prawa wyznaniowego i budowlanego nie był upoważniony do budowy kościoła. Nie zważając jednak na te obostrzenia kapłan zaangażował się w planowanie zaplecza dla inwestycji kościelnej. W dniu 28 lutego 1973 r. władze wskazały oficjalnie miejsce na budowę świątyni, którym była północno-zachodnia część osiedla Tysiąclecia. Po drugiej stronie, na przeciwległym zboczu, około $300 \mathrm{~m}$ od placu budowy kościoła, znajdowało się os. Złotego Wieku ${ }^{57}$.

23 lipca 1973 r. rozpoczęto budowę punktu katechetycznego wraz z kaplicą, kuchnią i kancelarią. Szybkie tempo prac spowodowało, że budynki te były gotowe już po 4 miesiącach. W listopadzie rzeczonego roku trzech krakowskich architektów opracowało konkursowe projekty nowej świątyni. Następnie Komisja ds. Budownictwa Sakralnego Kurii wybrała projekt autorstwa Józefa Dutkiewicza, który z drobnymi poprawkami został zatwierdzony przez władze miasta w dniu 21 października 1974 r. Ostateczna decyzja z planem realizacji kościoła w Mistrzejowicach została wydana przez Wydział Gospodarki Przestrzennej, Geodezji i Ochrony Środowiska w czerwcu 1975 r. Niemniej ,pierwszą łopatę” na budowie wkopano

56 B. Frydel, K. Szumal, Ks. kanonik Józef Kurzeja..., dz. cyt., s. 49-55.

57 B. Frydel, K. Szumal, Ks. kanonik Józef Kurzeja..., dz. cyt., s. 56-59. 
w ziemię podczas uroczystości poświęcenia inwestycji przez kard. Wojtyłę w dniu 14 maja 1975 r. $^{58}$

Dokładny projekt Dutkiewicza wpisywał się w naturalne uwarunkowania terenu (pochyłe zbocze) i przywidywał wykorzystanie podziemia świątyni na kaplicę i sale katechetyczne. Całkowita kubatura budowli miała wynieść $4460 \mathrm{~m}^{2}$. Koszt inwestycji oszacowano w $1974 \mathrm{r}$. na około $50 \mathrm{mln}$ zł. Wobec tego najpilniejszą potrzebą stawała się kwestia zgromadzenia potrzebnych środków finansowych - tym bardziej paląca, iż z szacunków księdza Kurzei wynikało, że parafianie mogą zebrać rocznie około $1 \mathrm{mln}$ ówczesnych złotych. Rozpoczęto zatem poszukiwania dodatkowego wsparcia pieniężnego. Udało się w niedługim czasie przekonać do mecenatu nad budową członka Zakonu Kawalerów Maltańskich Andrzeja Ciechanowieckiego, który wkrótce stał się największym ofiarodawcom na rzecz kościoła ${ }^{59}$.

Średnio dziennie przy budowie kościoła pracowało społecznie około 50 osób. Szybkie tempo prac spowodowało, że już w czerwcu 1976 r. zaczęto wznosić mury świątyni. Finalizacji budowy, ani erygowania parafii w Mistrzejowicach nie doczekał ksiądz Kurzeja, który po kilku miesiącach zdrowotnych perypetii zmarł nieoczekiwanie w dniu 15 sierpnia $^{60}$.

Tymczasem 14 listopada 1976 r. ukończono pierwszy etap budowy kościoła wieńcząc go wmurowaniem kamienia węgielnego. Latem 1977 r. wzniesiono dwie główne ściany świątyni. Rok później dokonano zabetonowania dachu obiektu. Natomiast we wrześniu 1979 r. zabetonowano wieżę kościoła, a w grudniu kontynuowano prace wykończeniowe w kaplicy i w salach katechetycznych. Wszystko to działo się pod czujnym okiem nowego proboszcza, kanclerza kurii krakowskiej, ks. prałata Mikołaja Kuczkowskiego. W dniu 23 grudnia wspomnianego roku kardynał Franciszek Macharski poświęcił tzw. dolną kaplicę o powierzchni $600 \mathrm{~m}^{2}$ i $6 \mathrm{sal}$ katechetycznych ulokowanych pod powierzchnią kościoła. Właśnie wówczas w tym obiekcie odbyła się pierwsza Msza Święta. Następnie od stycznia 1980 r. trwały na zewnątrz i wewnątrz świątyni prace wykończeniowe. W 1981 r. przystąpiono do tynkowania, które zakończono w kolejnym roku. Konsekracja świątyni miała miejsce w dniu 22 czerwca 1983 r. i dokonał jej będący wówczas z oficjalną wizytą w Polsce papież Jan Paweł II ${ }^{61}$.

Miejscem zmagań duchownych i wiernych z komunistycznymi władzami w sprawach związanych z szeroko rozumianym budownictwem sakralnym był także ośrodek duszpasterski w Mogile. Na obszarze administrowanym przez mogilską parafię,

58 J. L. Franczyk, Na fundamencie Krzyża..., dz. cyt., s. 220-224; B. Frydel, K. Szumal, Ks. kanonik Józef Kurzeja..., dz. cyt., s. 61.

59 J. L. Franczyk, Na fundamencie Krzyża..., dz. cyt., s. 223.

${ }^{60}$ B. Frydel, K. Szumal, Ks. kanonik Józef Kurzeja..., dz. cyt., s. 90; J. L. Franczyk, Na fundamencie Krzyża..., dz. cyt., s. 224-226.

${ }^{61}$ J. Łuszczek, Parafia pw. św. Maksymiliana Marii Kolbego w Mistrzejowicach, w: Nowa Huta - miasto krzyża i pracy..., dz. cyt., s. 83-85; B. Frydel, K. Szumal, Ks. kanonik Józef Kurzeja..., dz. cyt., s. 90-92. 
musimy w pierwszym rzędzie wspomnieć o działalności zakonników, dotyczącej rozbudowy infrastruktury religijnej oraz pomocniczej. Wielkie zasługi na tym polu położył ówczesny przeor klasztoru w Mogile o. Stożek, który niestrudzenie i często wbrew obowiązującemu prawu prowadził rozmaite inwestycje budowlane stając się obiektem szykan władz państwowych - przede wszystkim w okresie gomułkowskim, ale także w czasach Edwarda Gierka ${ }^{62}$. Z meldunku Referatu SB w Nowej Hucie do Naczelnika Wydziału IV SB KW MO w Krakowie opatrzonego klauzurą „tajne specjalnego znaczenia” dowiadujemy się dokładnie, jak groźny dla komunistów był o. Stożek. Jego postać wymieniana jest w raporcie jako posiadająca ogromny autorytet wśród zakonników. „Wymieniony jest znany jako pełny asceta i ideolog klasztoru przy tym nieustępliwy wobec władz państwowych"63.

$\mathrm{W}$ pierwszej połowie lat 70. XX w. szczególnie głośnym echem odbiła się sprawa ufundowania trzech symbolicznych dzwonów i wybudowania dzwonnicy w roku jubileuszowym 750-lecia przybycia cystersów do Mogiły. W listopadzie 1972 r. władze wydały decyzję o wstrzymaniu robót budowlanych, a równocześnie wezwały na rozmowę dyscyplinującą mogilskiego opata o. Bogumiła Salwińskiego. Dopiero przedłożenie odpowiedniego projektu budowlanego, wpłacenie 1200 zł na Fundusz Komitetu Budowy Pomnika Grunwaldzkiego, a dalej pozytywna opinia dotycząca dzwonnicy wydana przez miejskiego konserwatora zabytków, otworzyła drogę do pozwolenia na dokończenie inwestycji. Ostatnią instancją, która musiała jednak wyrazić zgodę na kontynuowanie budowy była tzw. nowohucka „trójka polityczna”. W skład tego kierowniczego gremium wchodzili na ogół I sekretarz KD PZPR, Naczelnik Dzielnicy oraz dzielnicowy Komendant MO lub jego zastępca. Szczęśliwie dla cystersów w styczniu 1973 r. władze wydały pozwolenie na dokończenie wspomnianej inwestycji ${ }^{64}$.

Sporym problemem parafian z Mogiły - szczególnie tych zamieszkujących w rejonie Placu Centralnego - była potrzeba budowy nowej świątyni wynikająca z wysokiej gęstość zaludnienia, a także niemałej odległości do cysterskiego opactwa. Co ciekawe, miejscem planowanej przez wiernych inwestycji miał być punkt, gdzie wedle historycznych źródeł od 1880 r. stał przydrożny krzyż na trasie z Mogiły do Bieńczyc. Ten symboliczny obiekt sakralny - początkowo drewniany, a w 1938 r. zmodernizowany na żelbetonowy - będący niemym świadkiem wielu przemian, które dokonywały się w jego okolicy miał być kolejny raz drogowskazem przeobrażeń. W dniu 6 czerwca 1977 r. delegacja parafian z Mogiły złożyła w Warszawie w kancelarii Rady Ministrów księgę próśb wraz z podpisami około 5 tys. wiernych ws. zezwolenia na budowę kościoła w centrum Nowej Huty. Po kilku tygodniach przyszła odmowna

${ }^{62}$ AKMKr, sygn. APA 203, Decyzja administracyjna PRN Wydział ds. Wyznań z dn. 5 IV 1971 r., k. 716-717; J. L. Franczyk, Na fundamencie Krzyża..., dz. cyt., s. 205-207.

${ }^{63}$ IPN Kr sygn. IPN Kr 021/25, t. 2, Pismo ppłk. Władysława Żyły do Naczelnika Wydziału IV SB KW MO w Krakowie z dn. 1 XII 1970 r., k. 28-33.

${ }^{64}$ ANKr, sygn. UD Kr-NH, 2026/529, Notatka z zebrania ds. kleru, k. 15; J. L. Franczyk, Na fundamencie Krzyża..., dz. cyt., s. 205-207. 
odpowiedź od Dyrektora Urzędu ds. Wyznań. Władze argumentowały ją brakiem materiałów i potrzebą rozwiązywania pilniejszych problemów resortu. Wierni nie dawali bynajmniej za wygraną organizując przy wsparciu duchowieństwa cykliczne nabożeństwa w plenerze wśród okolicznych bloków w intencji budowy rzeczonego kościoła. Dopiero jednak na kanwie wizyty Jana Pawła II w Mogile nastąpił przełom w sprawie. W dniu 5 marca 1981 r. Prezydent Miasta Krakowa wydał ostateczną decyzję zezwalającą na budowę kościoła i zaplecza duszpasterskiego w osiedlu Szklane Domy. W 1983 r. została erygowana w tym miejscu parafia pw. Matki Bożej Częstochowskiej ${ }^{65}$.

Przykłady zmagania nowohucian i lokalnego duchowieństwa z aparatem administracji państwowej o budowę nowych obiektów sakralnych oraz kościelnej infrastruktury pomocniczej z łatwością odnajdujemy również w segmencie pomniejszych peryferyjnych parafii. Jaskrawym dowodem na prowadzenie konsekwentnej administracyjnej polityki możliwie długiego blokowania planowanych przez Kościół inwestycji budowlanych była sprawa plebani w Czyżynach. Wobec jej braku księża sprawujący posługę w tym ośrodku duszpasterskim zmuszeni byli zamieszkiwać w okolicach kościoła, aczkolwiek nie w bezpośredniej jego bliskości. W związku z powyższym tymczasowa kancelaria parafii mieściła się w miejscu zameldowanie proboszcza - a więc w lokalu prywatnym. To przez wiele lat utrudniało zarówno pracę duchownym, jak i swobodny dostęp do czynności kancelaryjnych wiernym ${ }^{66}$. Nie może zatem dziwić fakt, iż najważniejszą kwestią dla właściwego funkcjonowania czyżyńskiej parafii była potrzeba wybudowania właśnie obiektu kościelnego o takiej charakterystyce. Władze państwowe czyniły jednak rozmaite trudności, aby możliwie długo blokować zezwolenie na rozpoczęcie rzeczonej inwestycji. Widać to doskonale, czytając m.in. pismo skierowane przez zastępcę Naczelnika Dzielnicy do Wydziału ds. Wyznań z dnia 18 marca 1975 r., w ramach odpowiedzi do Kurii Metropolitalnej na prośbę wyrażenia pozytywnej opinii dotyczącej sprawy planowanej przez Kościół budowy plebanii. Państwowi urzędnicy wyraźnie odmawiają wydania wiążącej opinii pod pretekstem braku dostatecznej ilości danych na temat projektu inwestycji i programu użytkowania nowego obiektu ${ }^{67}$. Dopiero kilka lat później, a dokładnie w dniu 26 czerwca 1978 r. Wydział Gospodarki Przestrzennej i Administracji Urzędu Dzielnicowego wydał decyzję o pozwoleniu na budowę plebanii ${ }^{68}$.

${ }^{65}$ N. S. Karsznia, Powstanie parafii i budowa kościoła Matki Bożej Częstochowskiej w Nowej Hucie, Kraków 1994, s. 51-56; N. S. Karsznia, Kościół i klasztor Ojców Cystersów na os. Szklane Domy, w: Nowa Huta - miasto krzyża i pracy..., dz. cyt., s. 97; http://www. szklanedomy.cystersi.pl/duszpasterstwo/historia/ [dostęp: 31 I 2019 r.].

66 J. Gwizdoń, Kościół św. Judy Tadeusza w Czyżynach..., dz. cyt., s. 73.

${ }^{67}$ ANKr, sygn. UD Kr-NH, 2026/529, Pismo zastępcy Naczelnika Dzielnicy do Wydziału ds. Wyznań UW w Krakowie z dn. 18 III 1975 r., k. 25.

68 ANKr, sygn. UD Kr-NH, 2026/532, Notatka służbowa kierownika Wydziału z dn. 24 XI 1978 r., k. 77. 
Reasumując, możemy stwierdzić, iż w okresie gierkowskim na obszarze Nowej Huty pomimo rozmaitych trudności czynionych ze strony władz państwowych odnotowano dzięki przemyślanym działaniom przedstawicieli duchowieństwa oraz uporowi wiernych wykwit budownictwa sakralnego. Konsekwentna polityka „małych kroków" i stawiania częstokroć władz przed faktem dokonanym przyczyniła się z upływem czasu do legalizacji wcześniej nieaprobowanych przez komunistów obiektów kościelnych. Szeroko zakrojona budowa punktów katechetycznych i świątyń w nowohuckich parafiach w latach 70. XX w. ugruntowała pozycje Kościoła katolickiego i przyczyniła się do możliwości zintensyfikowania oraz rozszerzenia działań duszpasterskich - szczególnie w nowo wybudowanych osiedlach mieszkaniowych.

\section{BIBLIOGRAFIA}

\section{Źródła archiwalne:}

\section{Archiwum Instytutu Pamięci Narodowej Oddział w Krakowie:}

sygn. IPN Kr 021/25, t. 2, Korespondencja operacyjna Referatu SB KDMO w Krakowie Nowej Hucie z lat 1972-1975 dotycząca kontroli duchowieństwa na terenie dzielnicy Nowa Huta.

\section{Archiwum Kurii Metropolitalnej w Krakowie:}

sygn. AKMKr, APA 203, Parafia Mogiła (1970-1979).

sygn. AKMKr, APA 244, Parafia Pleszów.

sygn. AKMKr, APA 443, Parafia Bieńczyce.

sygn. AKMKr, APA 458, Parafia Mistrzejowice, cz. 1.

\section{Archiwum Narodowe w Krakowie:}

sygn. ANKr, UD Kr-NH, 2026/528, Sprawy wyznaniowe - dokumenty różne 1974. sygn. ANKr, UD Kr-NH, 2026/529, Sprawy wyznaniowe - dokumenty różne 1975. sygn. ANKr, UD Kr-NH, 2026/531, Sprawy wyznaniowe - dokumenty różne 1976. sygn. ANKr, UD Kr-NH, 2026/532, Sprawy wyznaniowe - dokumenty różne 19771979.

\section{Źródła drukowane:}

Katalog kościołów i duchowieństwa Archidiecezji Krakowskiej za rok 1967, Kraków 1967.

Katalog kościołów i duchowieństwa Archidiecezji Krakowskiej za rok 1972, Kraków 1972. 
Katalog kościołów i duchowieństwa Archidiecezji Krakowskiej za rok 1977, Kraków 1977.

Katalog kościołów i duchowieństwa Archidiecezji Krakowskiej za rok 1983, Kraków 1983.

\section{Źródla internetowe:}

http://www.wzgorza.diecezja.krakow.pl/article.php/20100207143410786 [dostęp: 28 I 2019 r.].

http://www.szklanedomy.cystersi.pl/duszpasterstwo/historia/ [dostęp: 31 I 2019 r.].

\section{Prasa:}

„Głos Nowej Huty” za rok 1977.

\section{Opracowania:}

Anioła J., Huta im. Lenina, Warszawa 1954.

Baniak E., Kościół Matki Bożej Królowej Polski w Bieńczycach, w: Nowa Huta miasto krzyża i pracy, red. J. L. Franczyk, M. Lasota, J. Szczepaniak, Kraków 2009.

Boniecki A., Kalendarium życia Karola Wojtyły, Kraków 2000.

Bober R., „Krzyże w mieście bez Boga”. Organizacja parafialna w Nowej Hucie w okresie działalności kard. Karola Wojtyly w latach 1962-1978, Kraków 2006.

Dudek A., Gryz R., Komuniści i Kościót w Polsce (1945-1989), Kraków 2006.

Franczyk J. L., Historia powstania parafii i kościoła w Mistrzejowicach, w: On tutaj byt... Karol Wojtyta w Nowej Hucie, oprac. red. R. Bober, W. Paduchowski, Kraków 2007.

Franczyk J. L., Na fundamencie Krzyża. Kościót katolicki w Nowej Hucie w latach 1949-1989, Kraków 2004.

Frydel B., Szumal K., Ks. kanonik Józef Kurzeja: „Pragnieniem moim jest wybudować kościót w Mistrzejowicach...”, Kraków 1998.

Gliksman A., Parafia i kościót św. Wincentego i Narodzenia Najświętszej Maryi Panny w Pleszowie, w: Nowa Huta - miasto krzyża i pracy, red. J.L. Franczyk, M. Lasota, J. Szczepaniak, Kraków 2009.

Głód J., Powstanie parafii i kościoła na Wzgórzach Krzesławickich, w: On tutaj byt... Karol Wojtyła w Nowej Hucie, oprac. red. R. Bober, W. Paduchowski, Kraków 2007.

Gołaszewski T., Kronika Nowej Huty, Kraków 1955.

Gorzelany J., Gdy nadszedt czas budowy Arki. Dzieje budowy kościoła w Nowej Hucie, Paryż 1988.

Gryz R., Pozwolić czy nie? Władze PRL wobec budownictwa katolickich obiektów sakralnych w latach 1971-1980, Kielce 2007. 
Gwizdoń J., Kościót św. Judy Tadeusza w Czyżynach, w: Nowa Huta - miasto krzyża i pracy, red. J. L. Franczyk, M. Lasota, J. Szczepaniak, Kraków 2009.

Karsznia N.S., Kościót i klasztor Ojców Cystersów na os. Szklane Domy, w: Nowa Huta - miasto krzyża i pracy, red. J. L. Franczyk, M. Lasota, J. Szczepaniak, Kraków 2009.

Karsznia N.S., Powstanie parafii i budowa kościoła Matki Bożej Częstochowskiej w Nowej Hucie, Kraków 1994.

Łuszczek J., Parafia pw. św. Maksymiliana Marii Kolbego w Mistrzejowicach, w: Nowa Huta - miasto krzyża i pracy, red. J. L. Franczyk, M. Lasota, J. Szczepaniak, Kraków 2009.

Natanek P., Rozwój organizacji dekanalnej, parafialnej i katechetycznej $w$ archidiecezji krakowskiej za rząów ks. kard. Karola Wojtyły (1962-1978), Kraków 1993.

Purchla J., Nowa Huta jako problem badawczy, w: Narodziny Nowej Huty: materiaty sesji naukowej odbytej 25 kwietnia 1998 roku, red. J. M. Małecki, Kraków 1999.

Raźny J., Organizacja sieci parafialnej na terenie Nowej Huty w XX wieku, w: On tutaj byt... Karol Wojtyła w Nowej Hucie, oprac. red. R. Bober, W. Paduchowski, Kraków 2007.

Ridan J., Krzyż nowohucki. Dzieje walki o wiarę i wolność, Krzeszowice 2006.

Skupień F., Rejonizacja parafii NMP Królowej Polski w Nowej Hucie, w: On tutaj byt... Karol Wojtyła w Nowej Hucie, oprac. red. R. Bober, W. Paduchowski, Kraków 2007.

Wroński J. S., Kościół Miłosierdzia Bożego na Wzgórzach Krzesławickich, w: Budujemy kościót. Wspótczesna architektura sakralna w Nowej Hucie, pod red. Michał Niezabitowski i in., Kraków 2010.

Żaryn J., Dzieje Kościoła katolickiego w Polsce (1944-1989), Warszawa 2003.

\section{Streszczenie}

Artykuł naukowy składa się zasadniczo z dwóch autonomicznych części oraz krótkiego wstępu i zakończenia. Pierwsza część rozpoczyna się od wyjaśnienia rzeczywistych realacji panujących na linii Kościół katolicki - państwo polskie w latach 70. XX w. Dalsza część tego rozdziału została poświęcona na szczegółowe omówienie istniejących w rzeczonym okresie na obszarze nowohuckiego dekanatu parafii wraz ze stanem faktycznym kadry duchownych oraz znajdujących się tam wówczas zakonów męskich i żeńskich. Część druga pracy zawiera natomiast drobiazgowy opis rozbudowy, remontów i budowy obiektów sakralnych na terenie poszczególnych parafii w Nowej Hucie w kontekście prowadzonej przez władze komunistyczne urzędowej ateizacji przestrzeni publicznej. Opis zmagań duchowieństwa i wiernych z lokalnymi władzami administracyjnymi o możliwość budowy nowych kościołów, a także punktów katechetycznych, ukazano na wy- 
branych przykładach z terenu parafii Bieńczyce, Pleszów, Mistrzejowice, Mogiła oraz Czyżyny.

Słowa klucze: Kościół katolicki, Nowa Huta, okres gierkowski, sieć parafialna, budownictwo sakralne

\section{The Catholic Church in Nowa Huta During the Gierek Period. The Development of the Parish Network and Religious Buildings \\ Summary}

This scientific article basically consists of two autonomous parts; a short introduction and an ending. The first part begins with an explanation of the prevailing realities between the Catholic Church and the Polish state in the 1970s. The first part of this chapter is devoted to a detailed discussion of the parishes in Nowa Huta which existed in that period, together with the actual state of the clergy and male and female religious orders located there. The second part of the work, however, contains a detailed description of the expansion, renovation and construction of sacred buildings in the area of individual parishes in Nowa Huta in the context of official atheisation of public space carried out by the communist authorities. The description of the struggle of the clergy and the faithful with local administrative authorities for the possibility of building new churches, as well as catechetical points, is shown by selected examples from the parishes of Bieńczyce, Pleszów, Mistrzejowice, Mogiła and Czyżyna.

Key words: Catholic church, Nowa Huta, the Gierek period, parish network, religious buildings 